US Army Corps of Engineers:

Prepared for the U.S. Army Corps of Engineers, Portland District, under an Interagency Agreement with the U.S. Department of Energy Contract DE-AC05-76RL01830

\title{
Hydroacoustic Evaluation of
} Overwintering Summer Steelhead Fallback and Kelt Passage at The Dalles Dam Turbines, Early Spring 2011

\section{FINAL REPORT}

\section{F Khan \\ IM Royer}

February 2012

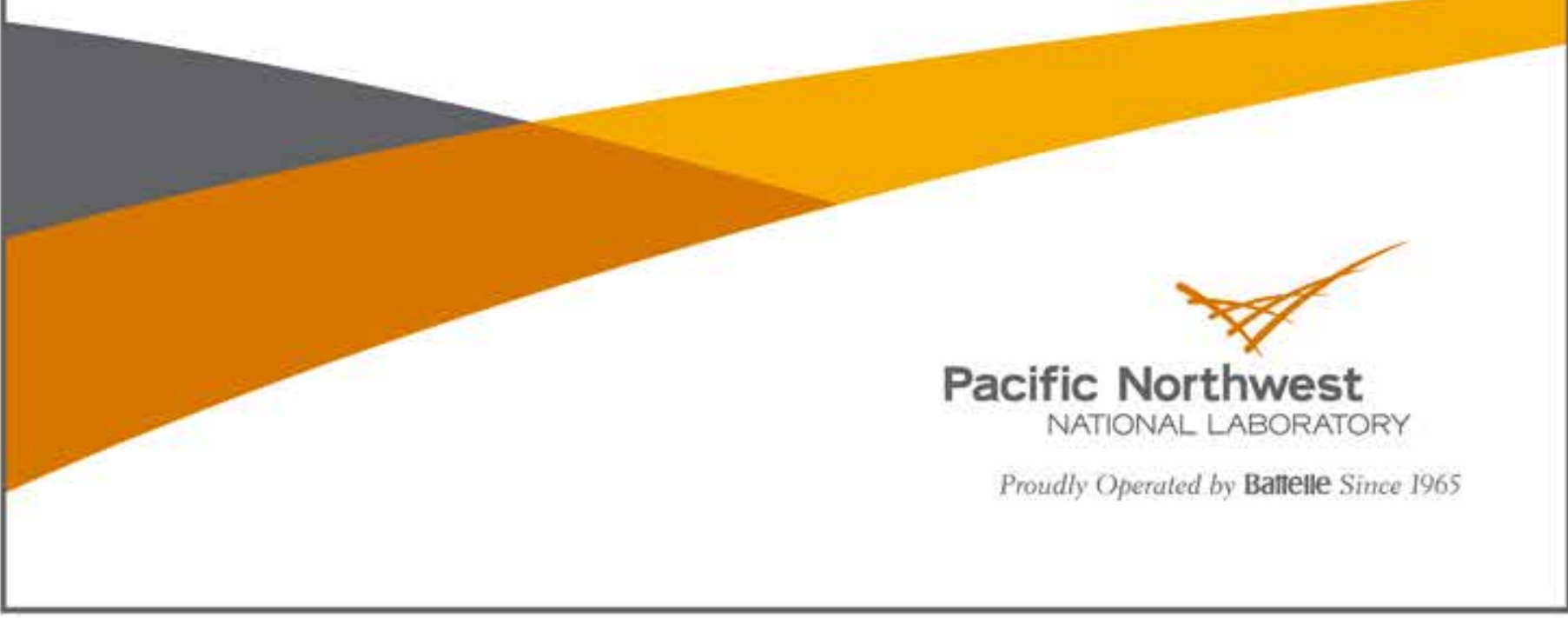




\title{
DISCLAIMER
}

This report was prepared as an account of work sponsored by an agency of the United States Government. Neither the United States Government nor any agency thereof, nor Battelle Memorial Institute, nor any of their employees, makes any warranty, express or implied, or assumes any legal liability or responsibility for the accuracy, completeness, or usefulness of any information, apparatus, product, or process disclosed, or represents that its use would not infringe privately owned rights. Reference herein to any specific commercial product, process, or service by trade name, trademark, manufacturer, or otherwise does not necessarily constitute or imply its endorsement, recommendation, or favoring by the United States Government or any agency thereof, or Battelle Memorial Institute. The views and opinions of authors expressed herein do not necessarily state or reflect those of the United States Government or any agency thereof.

\author{
PACIFIC NORTHWEST NATIONAL LABORATORY \\ operated by \\ BATTELLE \\ for the \\ UNITED STATES DEPARTMENT OF ENERGY \\ under Contract DE-AC05-76RL01830
}

Printed in the United States of America

Available to DOE and DOE contractors from the Office of Scientific and Technical Information,

P.O. Box 62, Oak Ridge, TN 37831-0062;

ph: (865) 576-8401

fax: (865) 576-5728

email: reports@adonis.osti.gov

\begin{abstract}
Available to the public from the National Technical Information Service, U.S. Department of Commerce, 5285 Port Royal Rd., Springfield, VA 22161 ph: (800) 553-6847 fax: (703) 605-6900

email: orders@ntis.fedworld.gov

online ordering: http://www.ntis.gov/ordering.htm
\end{abstract}

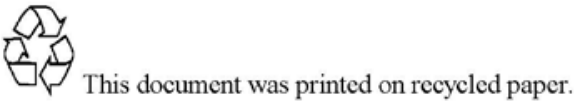

$(9 / 2003)$ 


\section{Hydroacoustic Evaluation of Overwintering Summer Steelhead Fallback and Kelt Passage at The Dalles Dam Turbines, Early Spring 2011}

Final Report

F Khan

IM Royer

February 2012

Prepared for

U.S. Army Corps of Engineers, Portland District

Under an Interagency Agreement with

the U.S. Department of Energy

Contract DE-AC05-76RL01830

Pacific Northwest National Laboratory

Richland, Washington 99352 



\section{Preface}

This study was funded as part of the Anadromous Fish Evaluation Program (AFEP), which is managed by the U.S. Army Corps of Engineers (USACE) to support management decisions about fisheries concerns at the eight federal dams on the lower Columbia and Snake rivers. The AFEP study codes for the research reported herein are ADS-P-00-1 - Evaluation of Adult Salmon and Steelhead Delay and Fallback at Dams on Snake and Columbia Rivers, and ADS-P-00-6 - Evaluation of Steelhead Kelt Passage through Columbia and Snake River Dams. The study was conducted by the Pacific Northwest National Laboratory (PNNL) for the USACE Portland District, whose technical lead was Sean Tackley (503 808 4751). The PNNL project manager was Fenton Khan (509 371 7230). The data are archived at PNNL offices in Richland, Washington. This final report is a project deliverable (PNNL Project No. 55449). 



\section{Executive Summary}

This report presents the results of an evaluation of overwintering summer steelhead (Oncorhynchus mykiss) fallback and early out-migrating steelhead kelts downstream passage at The Dalles Dam turbines during early spring 2011. The study was conducted by Pacific Northwest National Laboratory (PNNL) for the U.S. Army Corps of Engineers, Portland District (USACE) to investigate whether adult steelhead are passing through turbines during early spring before annual sluiceway operations typically begin. The sluiceway surface flow outlet is the optimal non-turbine route for adult steelhead, although operating the sluiceway reduces hydropower production. This is a follow-up study to similar studies of adult steelhead passage at the sluiceway and turbines we conducted in the fall/winter 2008, early spring 2009, fall/winter 2009, and early spring 2010.

The goal of the 2011 study was to characterize adult steelhead passage rates at the turbines while the sluiceway was closed so fisheries managers would have additional information to use in decision-making relative to sluiceway operations. Sluiceway operations were not scheduled to begin until April 10, 2011. However, based on a management decision in late February, sluiceway operations commenced on March 1, 2011. Therefore, this study provided estimates of fish passage rates through the turbines, and not the sluiceway, while the sluiceway was open.

The study period was March 1 through April 10, 2011 (41 days total). The study objective was to estimate the number and distribution of adult steelhead and kelt-sized targets passing into turbine units. We obtained fish passage data using fixed-location hydroacoustics with transducers deployed at all 22 main turbine units at The Dalles Dam.

Adult steelhead passage through the turbines occurred on 9 days during the study (March 9, 12, 30, and 31 and April 2, 3, 5, 7, and 9). We estimated a total of $215 \pm 98$ (95\% confidence interval) adult steelhead targets passed through the turbines between March 1 and April 10, 2011. Horizontal distribution data indicated Main Unit 18 passed the majority of fish. Fish passage occurred throughout the day. We conclude that adult steelhead passed through turbines during early spring 2011 at The Dalles Dam. 



\section{Acknowledgments}

The authors are grateful to the following people who contributed to this study:

- U.S. Army Corps of Engineers Personnel at The Dalles Dam: Robert Cordie, all of the project fish biologists, and the exceptional staff of the Operations, Electrical, and Structural and Maintenance crews.

- U.S. Army Corps of Engineers Personnel at Portland District Headquarters: Mike Langeslay, Natalie Richards, and Sean Tackley.

- Pacific States Marine Fisheries Commission: Aaron Cushing and Darin Etherington.

- PNNL: George Batten, Gayle Dirkes, Susan Ennor, Gary Johnson, Matthew Hennen, Julie Hughes, Kathy Lavender, Megan Peters, and Nathan Phillips.

- Precision Acoustic Systems: Alan Wirtz. 



\section{Acronyms and Abbreviations}

$\begin{array}{ll}\text { AFEP } & \text { Anadromous Fish Evaluation Program } \\ \mathrm{cfs} & \begin{array}{l}\text { cubic feet per second } \\ \mathrm{CI}\end{array} \\ \text { confidence interval } \\ \mathrm{dB} & \begin{array}{l}\text { Data Access in Real Time } \\ \text { decibel(s) }\end{array} \\ \mathrm{ft} & \text { foot/feet } \\ \mathrm{kcfs} & \text { thousand cubic feet per second } \\ \mathrm{kHz} & \text { kiloHertz } \\ \mathrm{m} & \text { meter(s) } \\ \mathrm{MSL} & \text { mean sea level } \\ \mathrm{MU} & \text { Main Unit - turbine intake } \\ \mathrm{NMFS} & \text { National Marine Fisheries Service } \\ \text { PAS } & \text { Precision Acoustic Systems } \\ \text { PNNL } & \text { Pacific Northwest National Laboratory } \\ \text { pps } & \text { pings per second } \\ \text { TDA } & \text { The Dalles Dam } \\ \mu \text { Pa } & \text { micro-Pascal } \\ \text { USACE } & \text { U.S. Army Corps of Engineers }\end{array}$





\section{Contents}

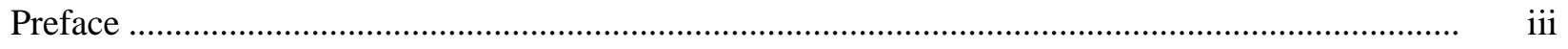

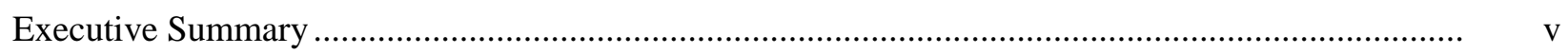

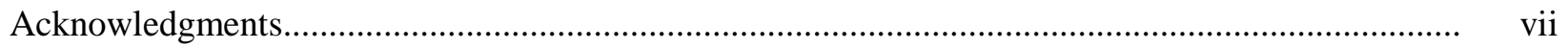

Acronyms and Abbreviations ............................................................................................. ix

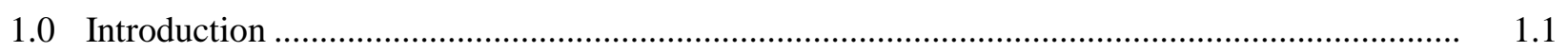

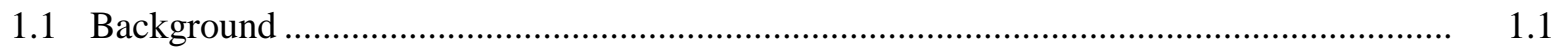

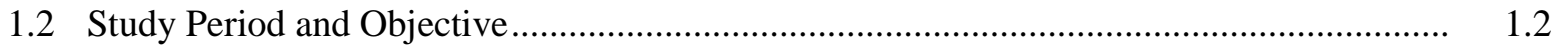

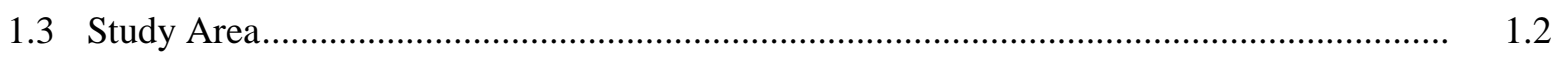

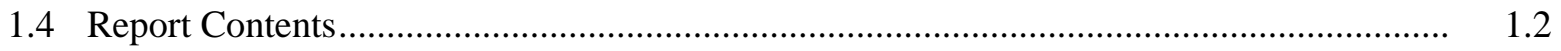

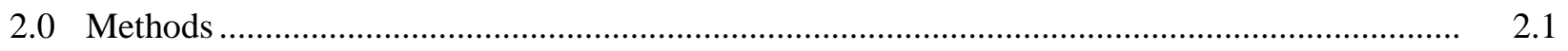

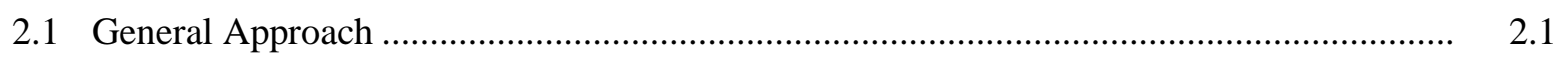

2.2 Fixed-Location Hydroacoustics ….............................................................................. 2.1

2.2.1 Hydroacoustic Systems ................................................................................... 2.1

2.2.2 Transducer Locations and Orientations........................................................... 2.2

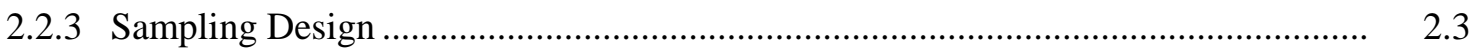

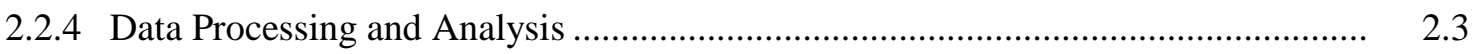

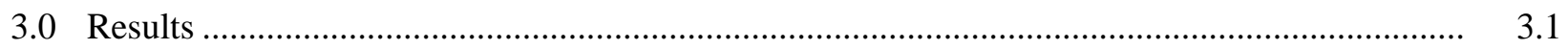

3.1 Environmental Conditions......................................................................................... 3.1

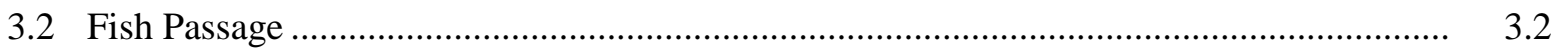

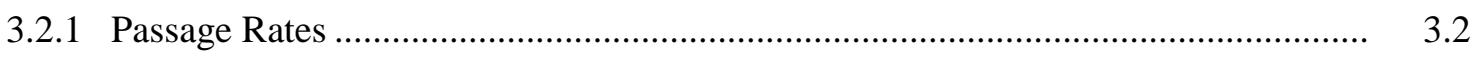

3.2.2 Horizontal Distribution ................................................................................ 3.2

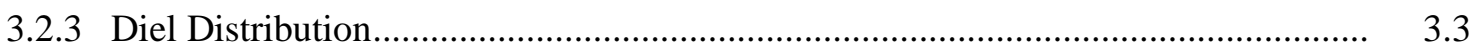

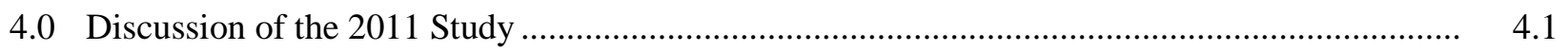

5.0 Three-Year Study Discussion ................................................................................................... 5.1

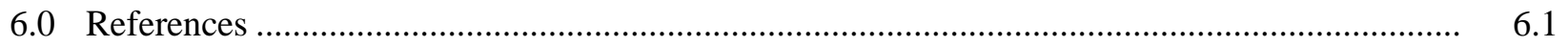

Appendix A - Adult Steelhead Upstream Passage at TDA Ladders ................................................ A.1

Appendix B - Adult Steelhead Downstream Passage Relative to Project Outflows........................... B.. B. 


\section{Figures}

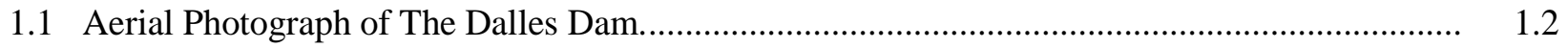

2.1 Plan View of The Dalles Dam Showing Transducer Locations at the Powerhouse .................... 2.2

2.2 Cross-Sectional View of a Main Unit Intake Transducer Deployment ...................................... 2.3

3.1 Total Outflow and 10-Year Average Outflow at TDA During the Study Period....................... 3.1

3.2 Forebay Elevation at TDA During the Entire Study Period ................................................... 3.1

3.3 Number of Overwintering Summer Steelhead Targets Passing Daily at Each Route of the Powerhouse from March 1 to April 10, 2011 .......................................................................... 3.2

3.4 Horizontal Distribution of Steelhead Targets Passage at Each Main Unit from March 1 to

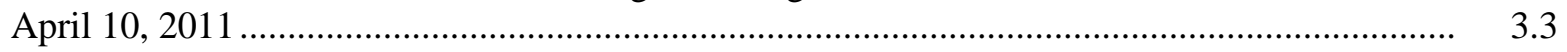

3.5 Diel Distribution of Steelhead Targets from March 1 Through April 10, 2011 ....................... 3.3

\section{Tables}

2.1 Sample Locations and Spatial Sampling Intensity at The Dalles Dam in 2011......................... 2.1

2.2 Mean Target Strength Filters .............................................................................................. 2.4

5.1 Summary of Adult Steelhead Passage at The Dalles Dam 2008-2011 ..................................... 5.1 


\subsection{Introduction}

This report presents the results of an evaluation of overwintering summer steelhead (Oncorhynchus mykiss) fallback and steelhead kelt downstream passage at The Dalles Dam (TDA) turbines during spring 2011. The study was conducted by the Pacific Northwest National Laboratory (PNNL) for the U.S. Army Corps of Engineers, Portland District (USACE). The goal of the study was to characterize adult steelhead spatial and temporal distributions and passage rates at the turbines at TDA for fisheries managers and engineers to use in decision-making for sluiceway operations to protect adult steelhead. This is the final study in a series of similar studies of adult steelhead passage at the sluiceway and turbines we conducted in the fall/winter 2008, early spring 2009, fall/winter 2009, and early spring 2010.

\subsection{Background}

After overwintering and spawning in freshwater, steelhead can migrate back downstream to the ocean in the spring. These downstream migrants, commonly referred to as kelts, may eventually return to freshwater spawning grounds to spawn again. This life history pattern is termed iteroparity. Kelts have to navigate through hydroelectric dams on their outward migration. The dams may delay migration timing and negatively affect survival of fish (Wertheimer and Evans 2005; Wertheimer et al. 2003). As with the fallback of overwintering summer steelhead, kelts pass the dam through available routes, including turbines and sluiceways. Khan et al. (2009, 2010) found adult steelhead are using the TDA sluiceway for downstream passage in early spring months before the start of the spill season for juvenile salmonids downstream passage.

The National Marine Fisheries Service (NMFS) stipulated in Reasonable and Prudent Alternative 54 of the 2008 Biological Opinion on operation of the Federal Columbia River Power System (NMFS 2008) that “...In addition to the current sluiceway operation (generally April 1-November 30), evaluate operation of The Dalles Dam sluiceway from March 1-March 31 and from December 1-December 15 as a potential means to provide a safer fallback passage route for overwintering steelhead and kelts, implement if warranted... Investigate surface-flow outlets during wintertime to provide safer fallback opportunity for over wintering steelhead (need will be determined by results of further research... Planning dates and voluntary operation of The Dalles Dam sluiceway may be adjusted (increased or decreased) through the adaptive management process or for research purposes."

Because steelhead are listed by the Endangered Species Act as endangered in the upper Columbia River and threatened in the Snake and mid-Columbia rivers (NMFS 2008), the USACE is dedicated to providing safe and timely passage for overwintering summer steelhead fallbacks and kelts at TDA. Providing optimal, non-fatal downstream routes at dams should improve return rates of kelts (Wertheimer and Evans 2005). The USACE 2006 Fish Passage Plan included operating the TDA sluiceway until November 30 as a route for fallbacks because of concerns about these fish using the turbines as a route through the dam. Operating the sluiceway reduces the potential for hydropower production, but this surface flow outlet may be the optimal non-turbine route for overwintering fallbacks in late fall and winter and kelt passage in early spring before the start of the voluntary spill season. 


\subsection{Study Period and Objective}

The study occurred from March 1 through April 10, 2011. The study objective was to estimate passage rates, run timing, horizontal distribution, and diel distribution for adult steelhead passing into the turbine units at TDA.

\subsection{Study Area}

The Dalles Dam (Figure 1.1) is located at river mile 192 and is the second closest dam in the Federal Columbia River Power System to the Pacific Ocean. It has a 2,090-ft-long powerhouse with 22 turbine units (main units), a total generating capacity of 1,800 megawatts, and a total hydraulic capacity of 375 kcfs. Full pool elevation is rated at $160 \mathrm{ft}$ above MSL (mean sea level is the reference level for all elevations in this report) and minimum operating pool elevation is $155 \mathrm{ft}$. The normal operating pool is at elevation $158 \mathrm{ft}$. The slope of the face of the powerhouse is $11.3^{\circ}$. The turbine intake ceiling intersects the trash racks at elevation $141 \mathrm{ft}$. The 1,380-ft-long spillway comprises 23 bays with 50 -ft wide radial gates.

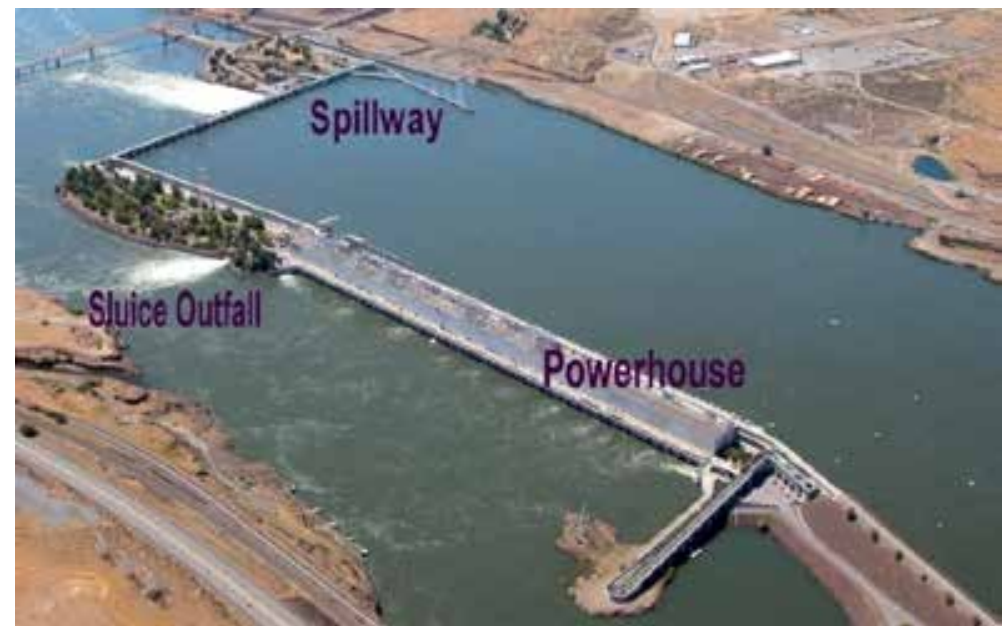

Figure 1.1. Aerial Photograph of The Dalles Dam. Flow is from right to left.

The ice-and-trash sluiceway is a rectangular channel that extends the entire length of the powerhouse. Sluice entrances are $20 \mathrm{ft}$ wide. Overall, sluiceway discharge is a relatively small proportion of total project discharge ( $\sim 2 \%)$. Flow into the sluiceway is dependent on forebay elevation and the number and location of open gates. For example, given a forebay elevation of $158 \mathrm{ft}$ and six open sluice gates (Main Unit [MU] 1-1, 1-2, 1-3, MU 5-2, and MU 18-1, 18-2), flows over the individual weir gates range from 564 cfs at MU 18-2 to 944 cfs at MU1-1, and total flow of 4,309 cfs (data provided by Stephen Schlenker, USACE).

\subsection{Report Contents}

The ensuing sections of this report include the 2011 study methods (Section 2.0), results (Section 3.0), discussion (Section 4.0), discussion of the results derived from the series of studies conducted over a 3-year period (for which the 2011 study reported here was the final year) (Section 5.0), and a list 
references cited (Section 6.0). Appendix A contains adult steelhead upstream passage at TDA ladders and Appendix B contains adult steelhead downstream passage relative to project outflows. 



\subsection{Methods}

The methods section includes descriptions of the general approach and the application of fixedlocation hydroacoustics for this study.

\subsection{General Approach}

The fixed-location hydroacoustic technique was used to accomplish the objectives of this study. This technique, conceived by Carlson et al. (1981) for single-beam acoustic systems, is described by Thorne and Johnson (1993). In addition to single-beam technology, split-beam technology is now an important element of fixed-location hydroacoustics. The split-beam technique is explained by MacLennan and Simmonds (1992). The methods used in this study were similar to those used in the 2004, 2005, and 2008/2009 hydroacoustic studies at TDA (Johnson et al. 2005, 2006; Khan et al. 2009, 2010).

The general approach was to deploy a combination of single-beam and split-beam transducers to sample fish, and apply the acoustic screen model (Johnson 2000) to estimate fish passage rates and distributions. Split-beam transducers provided data to determine weighting factors, assess assumptions of the model, and determine the magnitude of any biases. Split-beam transducer deployments at each type of passage route were used to estimate the average backscattering cross section of fish for detectability modeling and the direction of fish travel through sampling volumes to assess the assumptions of the acoustic screen model. Single- and split-beam transducers were deployed to sample fish passage at the turbines. Transducer sampling volumes were positioned to minimize ambiguity in assigning fish passage routes and the potential for multiple detections of the same fish.

\subsection{Fixed-Location Hydroacoustics}

Details about the hydroacoustic systems, transducer locations and orientations, sampling design, and data processing and analysis are provided in the following sections.

\subsubsection{Hydroacoustic Systems}

Data collection involved three Precision Acoustic Systems (PAS) single-beam hydroacoustic systems and six PAS split-beam systems. All systems operated at $420 \mathrm{kHz}$. The data-collection systems consisted of either Harp-1B (Single-Beam) or Harp-SB (Split-Beam) Data Acquisition/Signal Processing Software installed on a personal computer controlling a PAS-103 Multi-Mode Scientific Sounder. The PAS-103 sounders controlled transducers deployed in main turbine units and sluice entrances. A total of 22 transducers (18 single-beam and 4 split-beam) were deployed at the powerhouse (Table 2.1). During data collection, all systems used a voltage output threshold range of -26 to $-56 \mathrm{~dB}$ re: $1 \mu \mathrm{Pa}$ at $1 \mathrm{~m}$.

Table 2.1. Sample Locations and Spatial Sampling Intensity at The Dalles Dam in 2011

\begin{tabular}{|c|c|c|c|c|}
\hline Unit & $\begin{array}{l}\text { Intensity } \\
\text { by Unit }\end{array}$ & $\begin{array}{l}\text { Intensity by } \\
\text { Intake }\end{array}$ & $\begin{array}{l}\text { Number of } \\
\text { Transducers }\end{array}$ & Sample Locations \\
\hline Main Units 1-22 & 22 of 22 & 1 of 3 & 22 & $\begin{array}{l}\text { MU 1-1, 2-3, 3-1, 4-3, 5-1, 6-1, 7-2, 8-2, 9-2, 10-1, } \\
\text { 11-3, 12-2, 13-3, 14-2, 15-3, 16-3, 17-2, 18-2, 19-1, } \\
20-2,21-2,22-1\end{array}$ \\
\hline
\end{tabular}




\subsubsection{Transducer Locations and Orientations}

Single-beam transducers $\left(6^{\circ}\right)$ were installed at all turbine unit sampling locations, except for MU 2, MU 5, MU 16, and MU 18, each of which had a $6^{\circ}$ split-beam transducer (Figure 2.1). The intakes sampled at a given turbine unit were randomly chosen. At all turbine intake sampling locations, divers installed transducers on the bottom of the second to the bottom trash rack at elevation $75 \mathrm{ft}$ and aimed the transducers downstream and upward toward the intake ceiling at a $23^{\circ}$ angle to the plane of the trash rack (Figure 2.2). The transducer mounts were designed to fit between the vertical bars of the trash rack. This design allowed divers to secure the mount to the trash rack of each intake from the forebay. A diver took a transducer/mount/cable assembly to the bottom of the trash rack located just above the deepest installed rack (Figure 2.2). The diver then installed the mount between two vertical bars of the trash rack at elevation $75 \mathrm{ft}$ and secured the mount to the trash rack with "J" bolts.

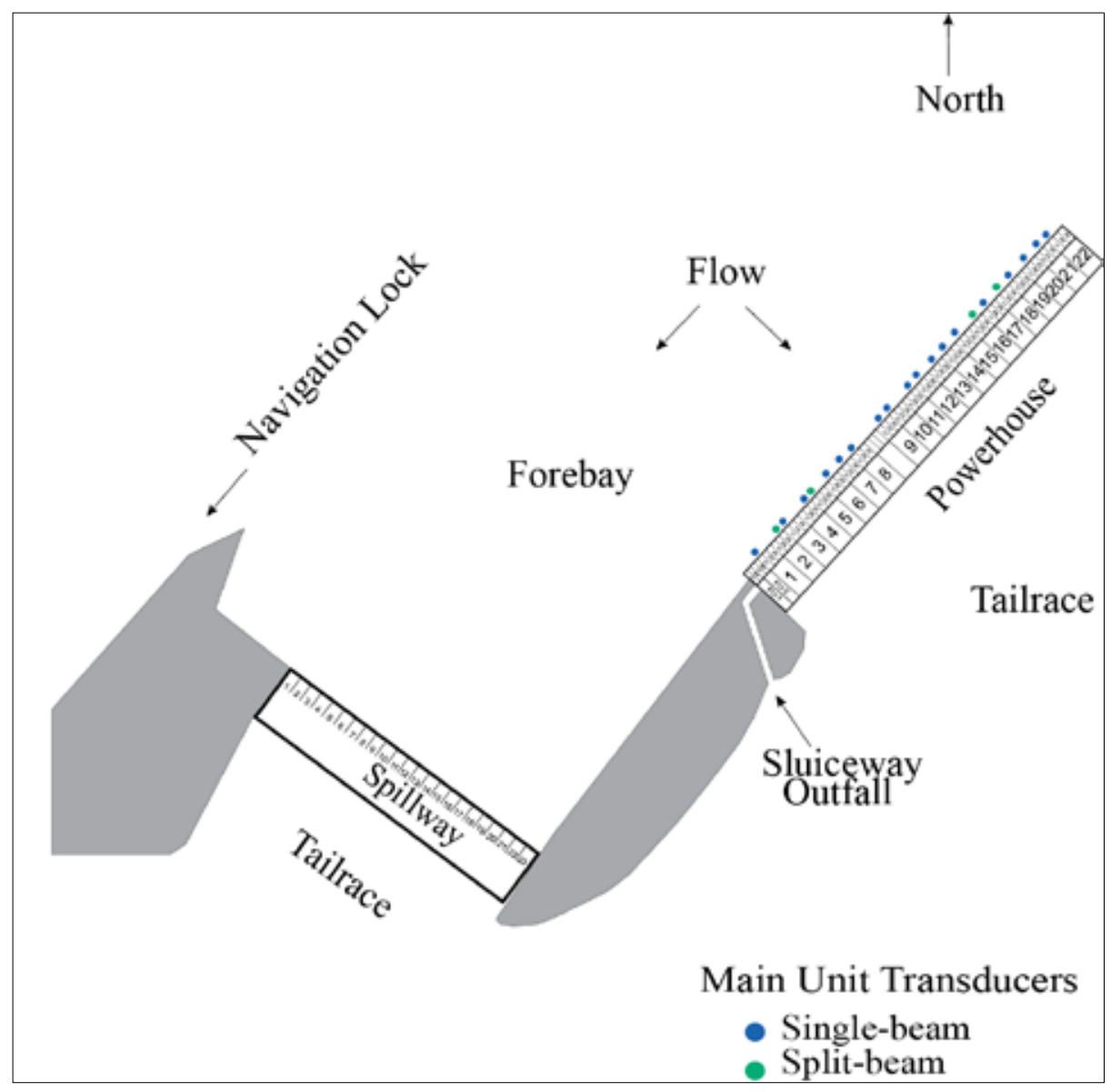

Figure 2.1. Plan View of The Dalles Dam Showing Transducer Locations at the Powerhouse. The spillway and sluiceway were not sampled. 


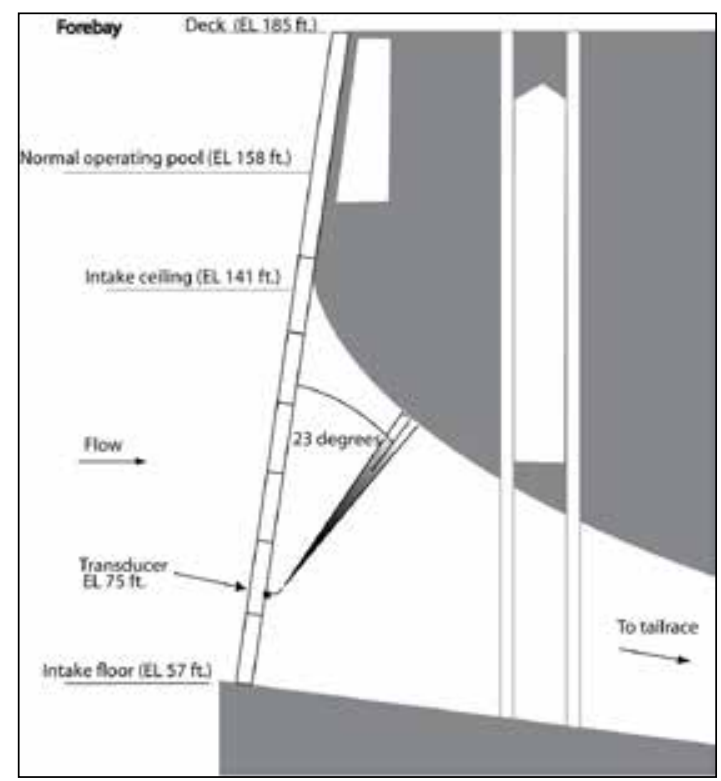

Figure 2.2. Cross-Sectional View of a Main Unit Intake Transducer Deployment

\subsubsection{Sampling Design}

Echo sounder transmission rates were 15 pps (pings per second). Systematic samples, i.e., same order among sampling locations each hour, were collected at 1-minute intervals 24 hours/day. Each location was sampled 10 or 30 times per hour depending on the number of transducers connected to the echo sounder.

\subsubsection{Data Processing and Analysis}

After the acoustic echo data were collected and archived, they were processed to extract fish tracks. At this stage in the analysis, we were careful to set the tracking parameters to include all fish at the expense of including spurious tracks. Next, to separate acceptable from unacceptable tracks, we filtered the data using fish tracks characteristics such as mean target strength, slope, speed, and pulse width. Subsamples of the data were manually checked to confirm that valid fish tracks remained after filtering. Data processing and reduction methods were similar to those used by Khan et al. $(2009,2010)$ and Johnson et al. (2005). Mean target strength as an indicator of fish size was used to distinguish relatively large adult steelhead fallback and kelt passage from smaller targets such as juvenile shad. The maximum target strength was set at $-26 \mathrm{~dB}$ re: $1 \mu \mathrm{Pa}$ at $1 \mathrm{~m}$ during data collection. During data processing, we filtered for large fish using mean target strengths previously used by Khan et al. (2009, 2010) (Table 2.2) based on the expected sizes of the smallest fish of interest of about $30 \mathrm{~cm}$ (personal communication from R. Wertheimer, USACE) and the relationship between fish length and target strength for adult salmon in side aspect described by Burwen and Fleischman (1998). The 3-dB difference between sluice and turbine target strengths accounted for the side and ventral aspects of insonification of fish by the respective deployments. 
Table 2.2. Mean Target Strength Filters

\begin{tabular}{lcc}
\hline & $\begin{array}{c}\text { Late Fall and Winter } \\
\text { Steelhead Fallback }\end{array}$ & $\begin{array}{c}\text { Early Spring } \\
\text { Steelhead Passage }\end{array}$ \\
\hline Sluice & $-29 \mathrm{~dB}$ & $-31 \mathrm{~dB}$ \\
Turbine & $-32 \mathrm{~dB}$ & $-34 \mathrm{~dB}$ \\
\hline
\end{tabular}

The process used to estimate passage rates from filtered tracked fish involved spatial and temporal extrapolations. Briefly, each fish track that survived the filtering process was weighted spatially to account for the sample width of the acoustic beam at the target's mid-range relative to the width of the depth bin it sampled; i.e., fish passage at unsampled portions of a passage route was estimated by extrapolating from the sampled areas. Turbine estimates were multiplied by three because only one out of three intakes at a given unit was sampled. The sum of these weighted fish was then extrapolated temporally by the hourly sampling fraction (60/total hourly sample time per location).

The hourly passage rate data for each transducer were used to estimate various performance metrics. Equations for each estimator follow. Let $x_{i j k y}$ be the expanded fish passage count in the $i^{\text {th }}$ transducer ( $i=1, \ldots, x)$ during the $j^{\text {th }}$ hour $(j=1, \ldots, 24)$ of the $k^{\text {th }}$ day $\left(k=1, \ldots, d_{y}\right)$ during $y^{\text {th }}$ study period, where $d_{y}$ is the number of study-days in the $y^{\text {th }}$ study period (late fall 2008 or early spring 2009).

Total adult steelhead fallback (or kelt passage) for the $y^{\text {th }}$ study period was estimated by the formula

$$
\mathrm{PP}_{y}=\sum_{i=1}^{6} \sum_{j=1}^{24} \sum_{k=}^{d_{y}} x_{i j k y}
$$

Daily adult steelhead fallback (or kelt passage) for the $k^{\text {th }}$ day in the $y^{\text {th }}$ study period for analysis of run timing was estimated by the formula

$$
\S P_{k y}=\sum_{i=1}^{6} \sum_{j=1}^{24} X_{i j k y}
$$

Hourly adult steelhead fallback (or kelt passage) for the $j^{\text {th }}$ hour in the $y^{\text {th }}$ study period for analysis of diel distribution was estimated by the formula

$$
\sum_{j y}=\sum_{i=1}^{6} \sum_{k=1}^{d_{y}} X_{i j k y}
$$

Johnson et al. (2005) describe methods to estimate variances for the passage rate estimates. The variances associated with each passage rate estimate were likely underestimated because between-intake variability in passage within a given turbine unit could not be accounted for because of sampling limitations. Ninety-five percent confidence intervals (CIs) for total and daily passage rates were calculated as follows:

$$
C I= \pm 1.96 * \sqrt{\text { Variance }}
$$




\subsection{Results}

The results from the study are organized into two main sections: environmental conditions and fish passage evaluation.

\subsection{Environmental Conditions}

Daily outflow at TDA ranged from 174 to 375 kcfs from March 1 through April 10, 2011

(Figure 3.1). Mean daily outflow was $240 \mathrm{kcfs}$. Discharge was above the 10-year average for the entire study period, with levels on April 5 peaking at $150 \%$ of the 10-year average (Figure 3.1). Voluntary spill for the juvenile salmonid out-migration, which normally begins on April 10, commenced on March 31 due to high water flows. Forebay elevation at TDA ranged from 157.3 to $159.2 \mathrm{ft}$, with an average elevation of $158.4 \mathrm{ft}$ above MSL (Figure 3.2).

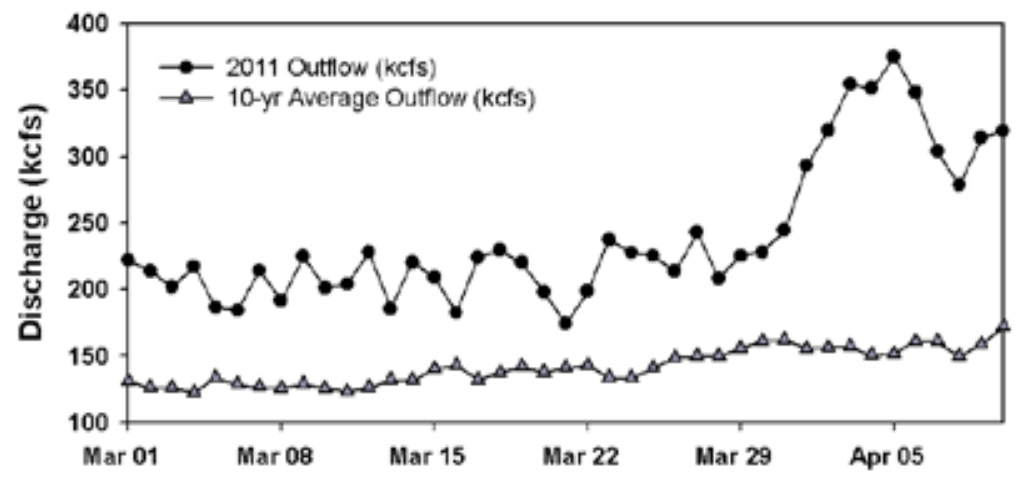

Figure 3.1. Total Outflow and 10-Year Average Outflow (kcfs) at TDA During the Study Period (March 1 - April 10, 2011). Data were obtained from Data Access in Real Time (DART; http://www.cbr.washington.edu/dart/dart.html), accessed on May 15, 2011.

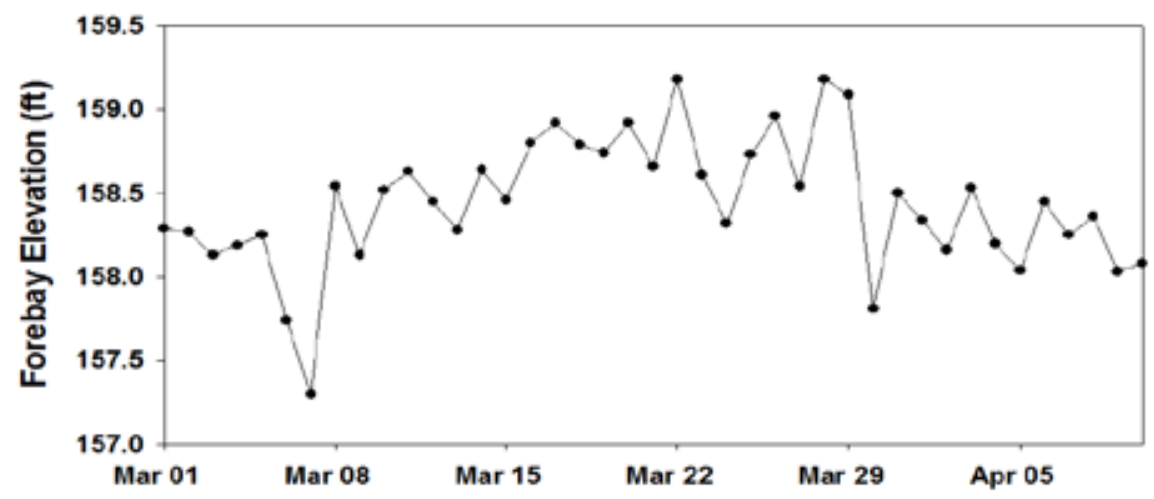

Figure 3.2. Forebay Elevation (feet above MSL) at TDA During the Entire Study Period (March 1April 10, 2011). Forebay data were obtained from DART (http://www.cbr.washington.edu/dart/dart.html), accessed on May 15, 2011. 


\subsection{Fish Passage}

Fish passage results are presented in sections on passage rates, run timing, horizontal distribution, and diel distribution.

\subsubsection{Passage Rates}

A total of $215 \pm 98$ (95\% CI) adult size steelhead targets passed through the powerhouse intakes during the 41-day study period. Fish were detected passing the turbines on 9 days during the study (March 9, 12, 30, and 31 and April 2, 3, 5, 7, and 9) (Figure 3.3). Because we did not conduct a sluiceway passage study and the sluiceway was unexpectedly opened at the start of the study period, the total number of fish passing TDA during this period is unknown.

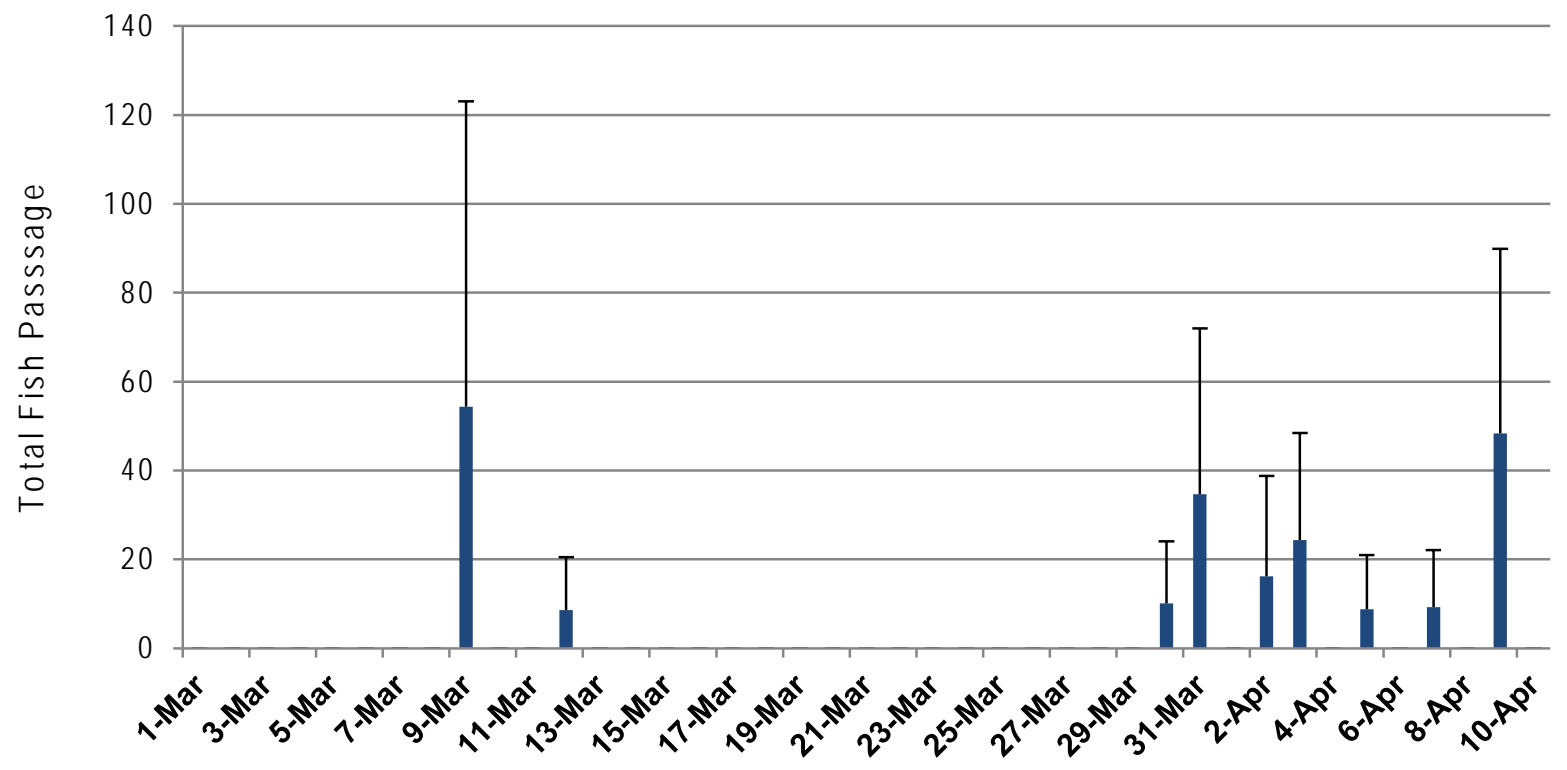

Figure 3.3. Number of Overwintering Summer Steelhead Targets Passing Daily at Each Route of the Powerhouse from March 1 to April 10, 2011 (95\% CI)

\subsubsection{Horizontal Distribution}

Total fish passage was highest at MU 18 (80 targets). MU 5 passed the second highest number of fish (70) and MU 8 passed 54 fish (Figure 3.4). 


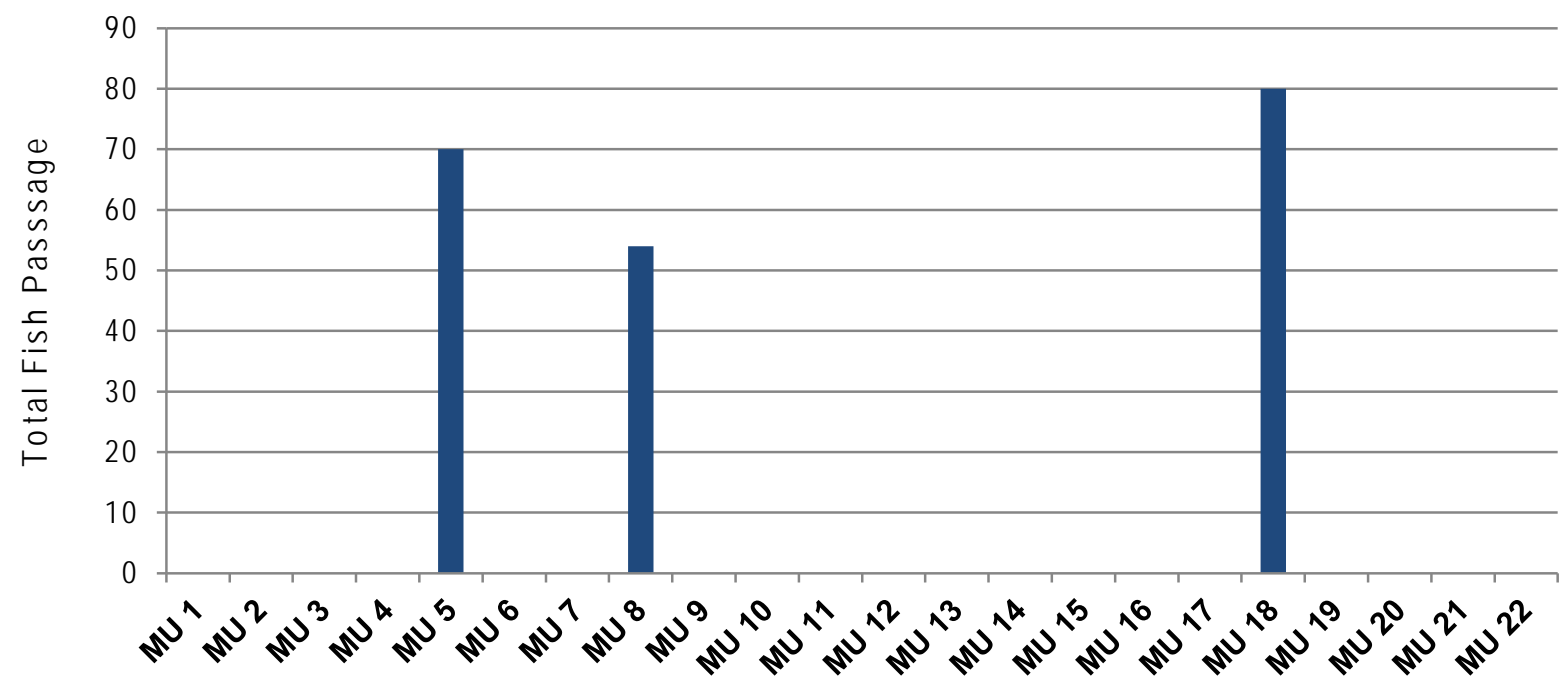

Figure 3.4. Horizontal Distribution of Steelhead Targets Passage at Each Main Unit from March 1 to April 10, 2011 (MU = main unit)

\subsubsection{Diel Distribution}

Diel distribution was variable, with fish passing the turbines throughout the day. However, passage was higher during mid morning, afternoon, and evening periods (Figure 3.5).

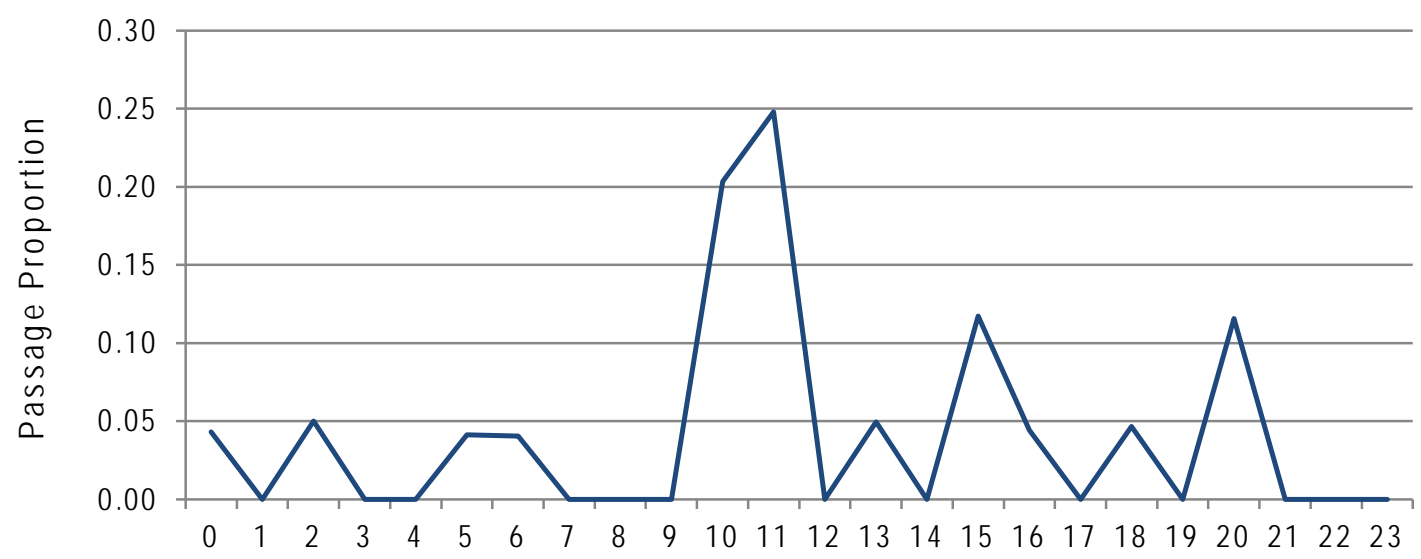

Figure 3.5. Diel Distribution of Steelhead Targets from March 1 Through April 10, 2011. Data are the hourly proportions of total passage. 



\subsection{Discussion of the 2011 Study}

We conducted a hydroacoustic study at TDA from March 1 through April 10, 2011 to evaluate fallback of overwintering summer steelhead and passage of out-migrating steelhead kelt at the powerhouse turbines in early spring. The overall goal of this 2011 study was to provide information about adult steelhead fallback and kelt downstream passage rates at the turbines, while the sluiceway was closed, to support decisions about the operations of the sluiceway in early spring months to allow adult steelhead passage through that route, thereby reducing turbine passage to improve steelhead survival as they pass the dam. The sluiceway is a surface flow outlet that may be the optimal non-turbine route for fallbacks and kelt passage in early spring before the start of the sluiceway operations and spill season for out-migrating juvenile salmonids. Johnson and Dauble (2006) concluded that surface flow outlets are prime routes for passing downstream migrating juvenile salmonids at dams. Operating the sluiceway, however, reduces the potential for hydropower production.

Initially, this was to be a turbine-only study, with the sluiceway closed between March 1 and April 10. However, in late February the fisheries managers decided to open the sluiceway for adult steelhead downstream passage on March 1. As a result, our study investigated adult steelhead passage through the turbines with the sluiceway open. We did not evaluate steelhead passage through the sluiceway because it was not part of the scope of study. During the study period, a total of $215 \pm 98$ (95\% CI) adult size steelhead targets passed through the turbines. Run timing peaked on March 9, with a second peak on April 10. Adult steelhead passage rates through the sluiceway are unknown, but we could speculate that large numbers (possibly thousands) passed through the sluiceway during this period based on results from similar studies we conducted during the two previous years (Khan et al. 2009, 2010).

Information from TDA Operations indicates all turbine units, except MU 16, were operated throughout the study period. Seven units (MU 4, 9, 10,11, 12, 13, 14) were out of service for a few days at a given time for maintenance and not all of these units were out of service at the same time. Therefore, almost all of the turbine units were available for adult steelhead to pass throughout the study; however, these fish were detected passing the turbines only on 9 days (March 9, 12, 30, and 31 and April 2, 3, 5, 7, and 9) and only passed though MU 5, 8, and 18 during the 9 days of passage. Our previous studies of springtime sluiceway passage (Khan et al. 2009, 2010) show large numbers of adult steelhead passed through the sluiceway (1,673 adult steelhead in 2009 and 1,958 in 2010); therefore, we speculate these fish were in the forebay (Wertheimer 2007; Keefer, 2008) and passing at the sluiceway during this study, and only a few sounded to pass through the turbines. Arnekliev et al. (2007) found that out-migrating smolts and kelts preferred a surface flow at a spillway to pass a hydropower dam instead of sounding to pass through submerged turbine shafts. Johnson et al., $(2005,2006)$ and Khan et al, $(2009,2010)$ found juvenile salmonids and adult steelhead migrating downstream through TDA preferred the sluiceway to turbines when the two were operated concurrently. Furthermore, Johnson et al. $(2005,2006)$ and Khan et al. (2009, 2010) found juvenile salmonids and adult steelhead passed at turbines below an open sluice entrance when they were operated concurrently. In the spring of 2011, sluice entrances at MU 1, 8, and 18 were opened, which may explain the reason adult steelhead passed though MU 8 and 18. No steelhead were observed passing MU 1, however 70 steelhead passed though MU 5. We saw adult steelhead using this route (MU 5) in our two previous studies (Khan et al. 2009, 2010). 
Diel distribution indicates adult steelhead passage was highly variable, which means these fish were passing the turbines at all times of the day. However, passage was higher during mid-morning, afternoon, and evening periods

Previous studies of adult steelhead passage through the sluiceway far exceeded passage through turbines even though only a fraction of powerhouse flow went through the sluiceway (Khan et al. 2009, 2010). Collectively, the results of these studies and our early spring 2011 study indicate that overwintering summer steelhead falling back during upstream migration in the fall and winter months and kelts migrating downstream in winter and early spring used the sluiceway and turbines as routes through the dam. We conclude that adult steelhead passed through turbines during early spring 2011 at TDA. 


\subsection{Three-Year Study Discussion}

The study reported in the previous sections was the final study of a three-year seasonal study of adult steelhead (fallbacks and kelts) downstream passage at TDA sluiceway and turbines to determine optimal sluiceway operations to provide a safe, non-turbine, route for these fish to pass the dam. We evaluated downstream passage of adult steelhead at the sluiceway and turbines during late fall/winter and early spring months of 2 years and at the turbines during the winter of 2009/2010 (see Khan et al. 2009, 2010) and spring of 2011 (this report) (Table 5.1). The sluiceway was operated during the spring 2011 turbine study, but fish passage through this route was not part of the scope of study and therefore, not sampled. This discussion summarizes the results of the overall 3-year study and provides a recommendation for sluiceway operations at TDA as a non-turbine route for adult steelhead downstream passage through the dam.

Table 5.1. Summary of Adult Steelhead Passage at The Dalles Dam 2008-2011

\begin{tabular}{lcccc}
\hline Sampling Period & $\begin{array}{c}\text { Total Passage } \\
\text { 95\% C.I.) }\end{array}$ & $\begin{array}{c}\text { Sluiceway } \\
\text { Passage }\end{array}$ & $\begin{array}{c}\text { Turbine } \\
\text { Passage }\end{array}$ & $\begin{array}{c}\text { Turbine Passage } \\
\text { (\% Total) }\end{array}$ \\
\hline (A) Nov 1 - Dec 15, 2008 & $1790 \pm 250$ & 1704 & 86 & $4.8 \%$ \\
(B) Mar 1 - Apr 10, 2009 & $1766 \pm 277$ & 1673 & 93 & $5.3 \%$ \\
(C) Nov 1 - Dec 15, 2009 & $879 \pm 165$ & 804 & 75 & $8.5 \%$ \\
(D) Dec 16, 2009 - Mar 7, 2010 & $62 \pm 40$ & Closed & 62 & $100 \%$ \\
(E) Mar 8 - Apr 10, 2010 & $1985 \pm 234$ & 1958 & 27 & $1.4 \%$ \\
(F) Mar 1 - Apr 10, 2011 & $215 \pm 98$ & Open, unknown & 215 & Unknown \\
\hline
\end{tabular}

For the overall study, we found the sluiceway was highly used by adult steelhead (91-99\% of total fish sampled passing the dam) during late fall/winter and early spring months. Wertheimer and Evans (2005), who conducted a radiotelemetry study of steelhead kelts at multiple dams on the Columbia and Snake rivers, found that during periods of non-spill, as experienced during our study, passage efficiency of TDA sluiceway was $64.3 \%(\mathrm{~N}=28,2001)$. Although our estimated sluiceway passage efficiency of 91-99\% is higher than theirs, this difference may be attributed to their small sample size, the high variance in our samples, or a difference in passage rates between post-spawn (kelts) and pre-spawn (fallback) steelhead. The latter likely compose the majority of the adult steelhead in our study because pre-spawn steelhead may overwinter in the reservoir and some may fall back through the dam in early spring to get to natal streams (NMFS 2003; Keefer et al. 2008). Regardless, the two studies show a high percentage of adult steelhead use the sluiceway as a route of downstream passage through the dam compared to the low numbers that passed through the turbines.

The average number of steelhead passing the turbine units per day differed among our study periods and years, but the numbers were low compared to the numbers passing at the sluiceway (Table 5.1). This variability is most likely ascribed to changes in flow, fish availability from year to year, and their proclivity to pass the turbines. We estimated low numbers of adult steelhead passing the turbines when the sluiceway was closed in the winter ( 0.8 fish/day). However, we saw an increase in turbine passage (5.2 steelhead per day) in the spring of 2011, when unusually high river flows were recorded at the dam (flows peaked at $375 \mathrm{kcfs}$ on April 5, 2011) (Appendix B.1). Regression analysis indicates that the total turbine passage for each study period over the 3 years was correlated with average outflow $\left(R^{2}=0.95\right.$, $p$ value $=0.001)$, but sluiceway passage was not $\left(\mathrm{R}^{2}=0.05\right.$, $\mathrm{p}$-value $\left.=0.8\right)$ (Appendix B.2). A lack of 
correlation with the sluiceway is consistent with the fact that sluiceway outflow is constant and does not change with increasing project outflow. We, therefore, conclude that the lack of a sluiceway route does not result increased turbine passage.

Arnekliev et al. (2007) found that out-migrating smolts and kelts preferred a surface flow at a spillway to pass a hydropower dam, when given the opportunity, and few of these fish sounded to $0.5 \mathrm{~m}$ to pass through a fishway entrance, while no fish sounded to $2.0 \mathrm{~m}$ to pass through submerged turbine shafts. Although our turbine-only study (sluiceway closed) in the winter of 2009-2010 may have been early for kelt passage, and steelhead fallbacks experience a nadir in January (Keefer et al. 2008), adult steelhead were still passing through the sluiceway prior to its closure on December 15 and immediately after its reopening on March 1, 2009 and March 8, 2010. Keefer et al. (2008) found that adult steelhead fallback occurred from November until spawning occurred in spring. Because we found adult steelhead passing the sluiceway on the last days before it was closed for the winter and again on the day it was opened for spring passage, these fish are likely available to pass during winter months while the sluiceway is closed, but are choosing not to sound and travel through the turbines; instead they are likely holding in the forebay above the dam waiting for a surface flow outlet (that is, the sluiceway). Kemp et al. (2005) found large size smolts were reluctant to pass into confined, dark spaces with increasing water velocities. Arnekliev et al. (2007) suggests kelts may be exhibiting similar behavior because of body size. In their study of different spill operations, Arnekliev et al. (2007) found kelts would traverse the dam during bottom spill and would only pass downstream during surface spill operations.

The large numbers of returning adult steelhead counted at TDA fish ladders (approximately 300, 000515, 000 between 2008 and 2010) (Appendix A.1) indicate reasonably large numbers of these fish may fall back through the dam in fall and winter months or may migrate downstream to the ocean in early spring as post-spawned kelt. Because the sluiceway is normally closed on November 30 for the winter, the only available route for steelhead falling back at the dam is the turbines, if they choose to sound and pass. The sluiceway is opened on April 1 for juvenile salmon out-migration, whereas kelt out-migration may begin as early as March; therefore, this operation may have consequences for kelt survival unless it is changed. Kelts migrating to the ocean are capable of returning to their freshwater spawning grounds to spawn again, which is an important factor for maintaining stable steelhead populations in their native rivers (Wertheimer and Evans 2005; Wertheimer 2007). Johnson et al. (2005, 2006) found the sluiceway at TDA to be an efficient and effective route for juvenile salmonids as they migrate downstream.

Arnekliev et al. (2007) found kelts prefer a surface flow outlet over bottom spill or turbines to pass a dam during out-migration.

The results of the overall 3-year study show that adult steelhead, most likely fallbacks (Keefer et al. 2008), were present and passed through the sluiceway in the fall and early winter, and continued to pass up to the day the sluiceway was closed December 15. On the first day the sluiceway was opened the following spring (March 1), a mix of adult steelhead fallbacks and kelts (Keefer et al. 2008; Wertheimer 2007) were present and readily passed into the sluiceway. Few steelhead passed the dam via turbines during the winter turbine-only study (December 162009 through March 7 2010).

Fallback of overwintering summer steelhead and passage of out-migrating kelt are examples of the benefits of using the sluiceway, instead of turbines, to pass adult steelhead during winter and early spring months. All 13 dams on the mainstem Columbia and Snake rivers with upstream passage facilities for adult salmonids have installed or are developing surface flow outlets to pass juvenile salmonids. Fisheries and hydrosystem managers are considering the use of these structures to protect adult steelhead 
from hydropower turbines (NMFS 2008). In conclusion, we recommend operating the sluiceway during late fall, winter, and early spring to provide an optimal, non-turbine route for adult steelhead (fallbacks and kelts) during downstream passage at TDA. 



\subsection{References}

Arnekleiv, JV, M Kraabol, and J Museth. 2007. Efforts to aid downstream migrating brown trout (Salmo trutta L.) kelts and smolts passing a hydroelectric dam and a spillway. Hydrobiologia 582:5-15

Burwen DL and SJ Fleischman. 1998. Evaluation of Side Aspect Target Strength and Pulse Width as Potential Hydroacoustic Discriminators of Fish Species in Rivers. Canadian Journal of Fisheries and Aquatic Sciences 55:2492-2502.

Carlson TJ, WC Acker, and DM Gaudet. 1981. Hydroacoustic Assessment of Downstream Migrant Salmon and Steelhead at Priest Rapids Dam in 1980. APL-UW 8016, Applied Physics Laboratory, University of Washington, Seattle, Washington.

Johnson GE. 2000. Assessment of the Acoustic Screen Model to Estimate Smolt Passage Rates at Dams: Case Study at The Dalles Dam in 1999. Final report submitted to Waterways Experiment Station, U.S. Army Corps of Engineers, Portland District, Portland, Oregon, by BioAnalysts, Inc. Vancouver, Washington.

Johnson GE and DD Dauble. 2006. "Surface Flow Outlets to Protect Juvenile Salmonids Passing through Hydropower Dams.” Reviews in Fisheries Science 14:213-244.

Johnson GE, ME Hanks, F Khan, CB Cook, JB Hedgepeth, RP Mueller, CL Rakowski, MR Richmond, SL Sargeant, JA Serkowski, and JR Skalski. 2005. Hydroacoustic Evaluation of Juvenile Salmonid Passage at The Dalles Dam in 2004. PNNL-15180, final report submitted to the U.S. Army Corps of Engineers, Portland District, Portland, Oregon, by Pacific Northwest National Laboratory, Richland, Washington.

Johnson GE, F Khan, JB Hedgepeth, RP Mueller, CL Rakowski, MR Richmond, JA Serkowski, and JR Skalski. 2006. Hydroacoustic Evaluation of Juvenile Salmonid at The Dalles Dam Sluiceway, 2005. PNNL-15540, final report submitted to the U.S. Army Corps of Engineers, Portland District, Portland, Oregon, by Pacific Northwest National Laboratory, Richland, Washington.

Keefer, M.L., Boggs, C.T., Peery, C.A., and Caudill, C.C. 2008. Overwintering Distribution, Behavior, and Survival of Adult Summer Steelhead: Variability Among Columbia River Populations. North American Journal of Fisheries Management 28:81-96.

Kemp, P. S., M.H. Gessel, and J. G. Williams. 2005. Fine-Scale Behavioral Responses of Pacific Salmonid Smolts as They Encounter Divergence and Acceleration of Flow, Transactions of the American Fisheries Society,134:2, 390-398

Khan F, GE Johnson, and MA. Weiland. 2009. Hydroacoustic Evaluation of Overwintering Summer Steelhead and Kelt Passage at The Dalles Dam, 2008-2009. PNNL-18590, final report submitted to the U.S. Army Corps of Engineers, Portland District, Portland, Oregon, by Pacific Northwest National Laboratory, Richland, Washington.

Khan F, GE Johnson, and MA. Weiland. 2010. Hydroacoustic Evaluation of Overwintering Summer Steelhead and Kelt Passage at The Dalles Dam, 2009-2010. PNNL-19615, final report submitted to the 
U.S. Army Corps of Engineers, Portland District, Portland, Oregon, by Pacific Northwest National Laboratory, Richland, Washington.

MacLennan DN and EJ Simmonds. 1992. Fisheries Acoustics. Chapman and Hall, London.

National Marine Fisheries Service (NMFS). 2003. Preliminary conclusions regarding the updated status of listed ESUs of West Coast salmon and steelhead. West Coast Salmon Biological Review Team, Northwest Fisheries Science Center; Southwest Fisheries Science Center, Co-Manager Review Draft. (National Oceanic and Atmospheric Administration Fisheries) - Northwest Region, Seattle, Washington.

National Marine Fisheries Service (NMFS). 2008. Biological Opinion - Consultation on Remand for Operation of the Federal Columbia River Power System, 11 Bureau of Reclamation Projects in the Columbia Basin and ESA Section 10(a)(1)(A) Permit for Juvenile Fish Transportation Program. NMFS (National Oceanic and Atmospheric Administration Fisheries) - Northwest Region, Seattle, Washington.

Thorne R and G Johnson. 1993. A Review of Hydroacoustic Studies for Estimation of Salmonid Downriver Migration Past Hydroelectric Facilities on the Columbia and Snake Rivers in the 1980s. Reviews in Fisheries Science 1:27-56.

Wertheimer, R. H., and A. F. Evans. 2005. Downstream passage of steelhead kelts through hydroelectric dams on the lower Snake and Columbia rivers. Transactions of the American Fisheries Society 134:853865.

Wertheimer, R. H. 2007. Evaluation of a Surface Flow Bypass System for Steelhead Kelt Passage at Bonneville Dam, Washington. North American Journal of Fisheries Management 21:1, 21-29.

Wertheimer RH, PL Madson, and MR Jonas. 2003. Evaluation of Steelhead Kelt Project Abundance, Condition, Passage, and Conversion Rates Through Lower Columbia River Dams in 2002. U.S. Army Corps of Engineers, Portland District Fish Field Unit, Bonneville Lock and Dam, Cascade Locks, Oregon. 
Appendix A

Adult Steelhead Upstream Passage at TDA Ladders 



\section{Appendix A - Adult Steelhead Upstream at TDA Ladders}

To provide context for the downstream passage results of our study, we obtained counts of returning adult steelhead as they pass The Dalles Dam fish ladders during upstream migration in 2008, 2009, and 2010. Adult steelhead are counted visually at the ladders from April 1 to October 31 of any year by fishcounting personnel and the numbers are recorded. Video observations are generally used to count fish from approximately February 20 through approximately December 7. In 2008 and 2010, the total number of returning adult steelhead numbered approximately 300,000. In 2009, over 515,000 steelhead were counted at the ladders.

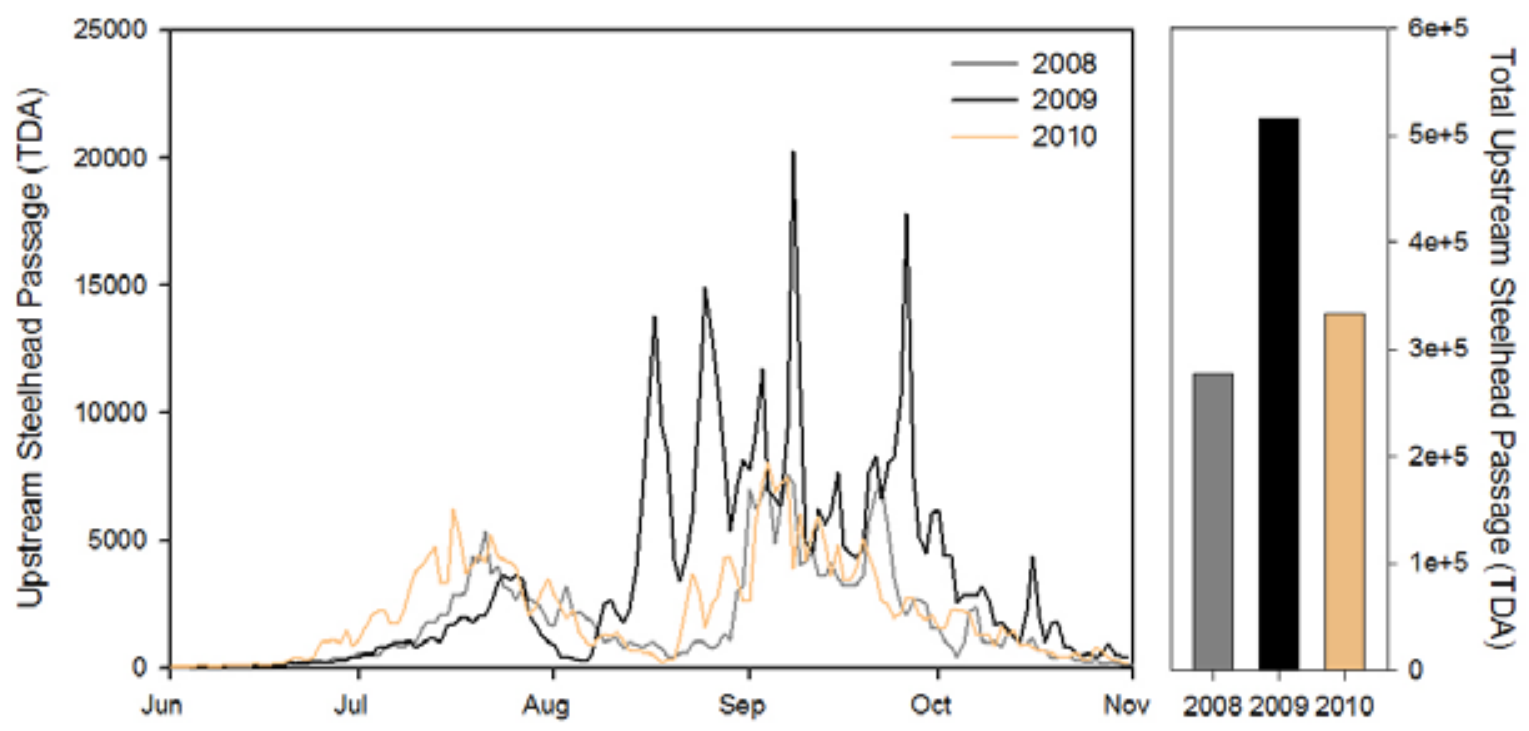

Figure A.1. Upstream Passage of Adult Steelhead Counted at The Dalles Dam Fish Ladders in 20082010. Visual counting generally begins on April 1 and ends on October 31 of any year. Video observations are generally used from February 20 through December 7. 

Appendix B

Adult Steelhead Downstream Passage Relative to Project Outflows 



\section{Appendix B - Adult Steelhead Downstream Passage Relative to Project Outflows}

Considering the variation in turbine passage rates and total outflow (kcfs) at the dam for all study periods, a regression analysis was conducted to determine whether turbine passage was related to outflow. A specific impetus was that the highest turbine passage rate in the spring of 2011 occurred after a winter of high snow pack and resultant high spring river flows (Figure B.1). The linear regression analysis show a strong association between turbine passage and mean outflow $\left(\mathrm{R}^{2}=0.95\right.$, $\mathrm{p}$-value=0.001) (Figure B.2). A linear regression analysis for sluiceway passage versus mean outflow indicated no association existed $\left(\mathrm{R}^{2}=0.05\right.$, $\mathrm{p}$-value $=0.8$ ) (Figure B.2).

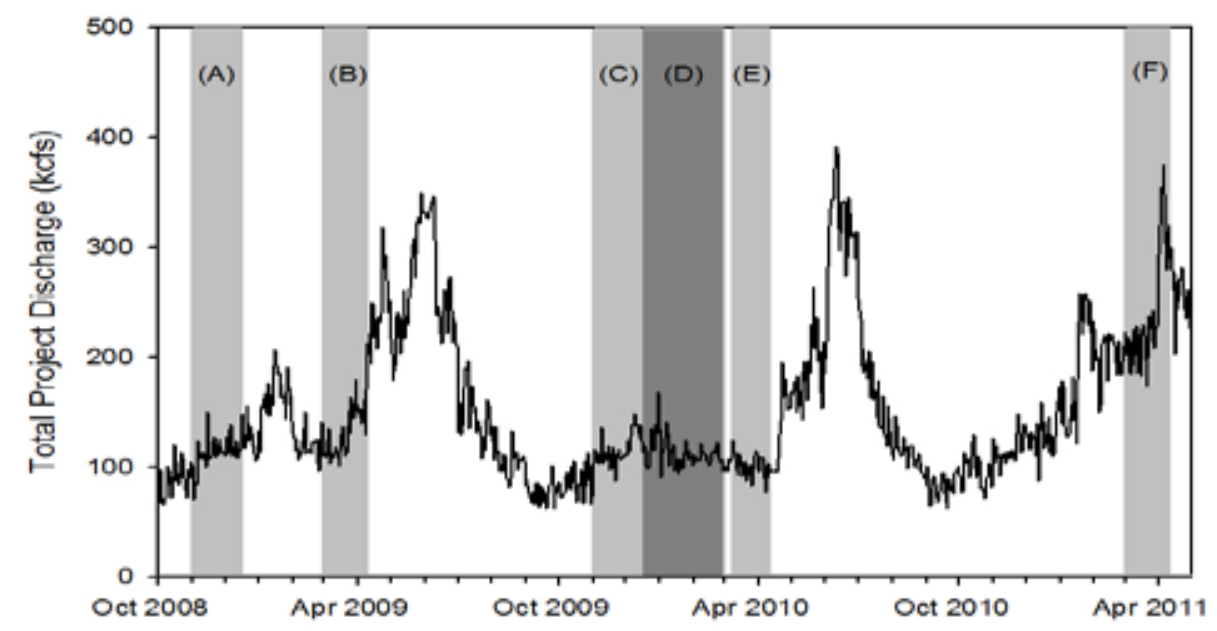

Figure B.1. Outflow at The Dalles Dam from October 2008 Through May 2011. Shaded regions correspond to the study periods listed in Table 4.1. 

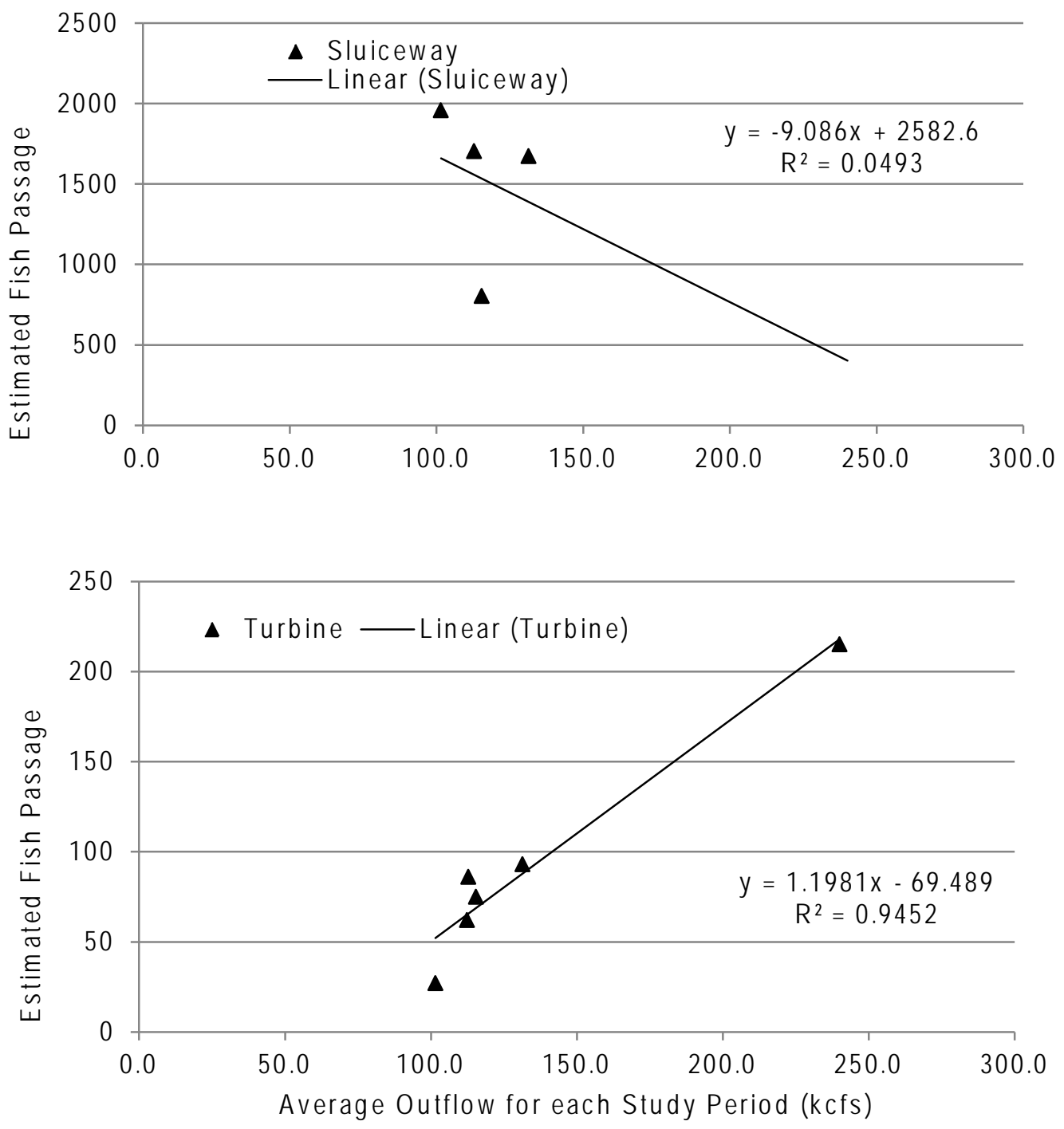

Figure B.2. Linear Regression of Estimated Fish Passage at the Sluiceway (top) and Turbines (bottom) Versus Mean Outflow 


\section{Distribution}

No. of

Copies (PDF)

OFFSITE

5 Sean Tackley

U.S. Army Corps of Engineers

P.O. Box 2946

Portland, OR 97208
No. of

Copies (PDF)

\section{ONSITE}

5 Pacific Northwest National Laboratory

$\begin{array}{lr}\text { KD Ham } & \text { K6-85 } \\ \text { GE Johnson } & \text { BPO } \\ \text { F Khan } & \text { K6-85 } \\ \text { GR Ploskey } & \text { NBON } \\ \text { MA Weiland } & \text { NBON } \\ \text { IM Royer } & \text { NBON }\end{array}$






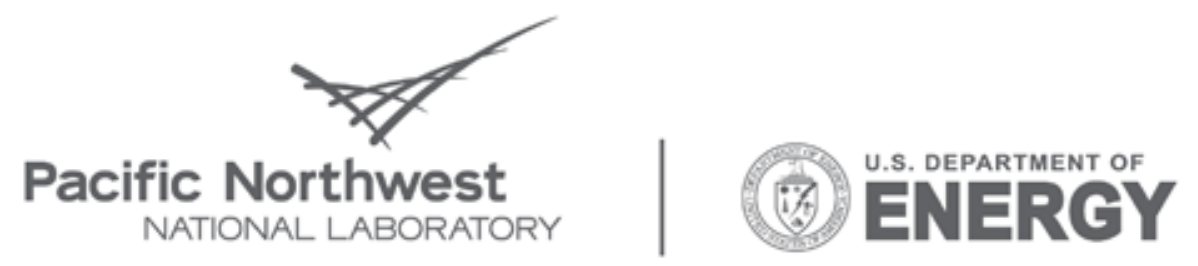

Proudly Operated by Battelle Since 1965

902 Battelle Boulevard

P.O. Box 999

Richland, WA 99352

1-888-375-PNNL (7665)

www.pnl.gov 